\title{
Research on the Training Mode of E-Commerce Talents' Innovation and Entrepreneurship Ability Based on the Cooperation Between School and Enterprise
}

\author{
Jiajia Ren ${ }^{1,2, a}$ \\ ${ }^{1}$ College of Logistics and E-commerce, Henan University of Animal Husbandry and Economy, \\ Zhengzhou 450044, China; \\ ${ }^{2}$ College of Management Science and Engineering, Dongbei University of Finance and Economics, \\ Dalian 116023, China \\ arenjiajia85@qq.com
}

Key words: School enterprise cooperation; E-commerce; Innovation and entrepreneurship

\begin{abstract}
School enterprise cooperation is an effective way to improve the innovation and entrepreneurship ability and practical ability of e-commerce professionals. On the basis of summarizing the existing mode of school enterprise cooperation of e-commerce specialty, this paper analyzes the existing problems of school enterprise cooperation in the cultivation of innovation and entrepreneurship ability of e-commerce specialty talents in China, and considers the orientation and division of labor and cooperation of universities, enterprises, governments and students in the process of e-commerce talents cultivation as a whole, and puts forward the innovation and Entrepreneurship of e-commerce talents from the macro and micro perspectives. The implementation path of ability training.

\section{基于校企合作的电子商务专业人才创新创业能力培养模式研究 \\ 任佳佳 ${ }^{1,2, a}$ \\ ${ }^{1}$ 河南牧业经济学院 物流与电商学院, 河南 郑州 450044 \\ 2 东北财经大学 管理科学与工程学院, 辽宁, 大连 116023 \\ arenjiajia85@qq.com \\ *任佳佳}

关键词：校企合作；电子商务；创新创业

中文摘要. 校企合作是提升电子商务专业人才创新创业能力和实践能力的有效途径。本文在 总结电子商务专业校企合作现有模式的基础上, 分析了我国电子商务专业人才创新创业能力 培养校企合作存在的问题，并统筹考虑高校、企业、政府、学生四方在电子商务人才培养过 程中的定位和分工协作，从宏观和微观视角下提出了电商专业人才创新创业能力培养的实施 路径。

\section{1.引言}

为了促进我国互联网经济快速、健康、可持续发展，电子商务专业人才的培养需要加强 校企合作，才能培养适应电子商务行业、企业发展需要的专业人才。电子商务专业人才培养 的校企合作需要学校、企业、学生、政府四方坚持“服务企业、企业需要、校企互动、校企互 
利、统一管理” 原则, 制定互利共赢的合作模式, 进而选择正确的教学方法, 才能通过校企合 作、工学结合的方式提高电子商务专业人才创新创业能力, 进而满足企业发展的需要。

\section{2.电子商务专业人才创新创业能力培养的校企合作模式}

\section{1 “订单式”培养模式}

目前，部分高校的电子商务专业为保证专业设置和就业率，采用“订单式”培养模式，即 通过与规模较大、信誉较好的电子商务企业开展合作，进行“订单式”培养，在培养的过程中， 高校结合电子商务企业的用人需求、岗位要求，与企业共同制定电子商务专业的人才培养方 案, 学生毕业后即可到合作企业参加工作。“订单式”的培养模式一方面保证了学生的就业, 同时也为电子商务企业发展提供了合适的人才。

\section{2 “工学交替, 顶岗实习”培养模式}

为了培养电子商务专业学生的实践能力, 目前, 大部分高校都采用了“工学交替, 顶岗实 习”的校企合作模式, 即在学生完成理论课程学习的基础上, 利用学期末的综合实训周或者寒 暑假的小学期进入企业进行顶岗实习, 也可以与企业结合, 借助双十一、“618”等电商年度活 动期间进入企业进行短期实习，这将有利于学生实践能力的提高。

\section{3 “引入企业, 实训承包”培养模式}

由开设电子商务专业的高校提供场地，引入电商物流类企业，在校内建设生产性实习基 地。引入电子商务企业, 实训承包的校企合作模式不仅能够解决高校实习实训场所及设备不 足的问题，同时也能够使企业与学校资源共享，有利于产学研的深入开展。

\section{4 “校企共训, 互助培养”培养模式}

部分深入开展校企合作的高校会组织专业教师和企业职业经理人共建互补型培训团队， 对高校学生和企业员工进行专业技能培训，这种“校企共训、互助培养”的模式能够使高校的 课程体系和企业的工作技能在校企合作过程中不断完善, 高校师生不仅能够锻炼实践技能, 帮助企业进行技术研发, 更有利于 “双师型” 教师的培养; 企业职业经理人也能够在这种合作 模式下丰富专业理论知识, 进而实现资源共享, 优势互补。

\section{3.我国电子商务专业人才创新创业能力培养的校企合作存在问题}

\section{1 电子商务专业人才培养校企合作的深度与广度有待加强}

目前，尽管我国电子商务专业人才培养的校企合作已经在高校普遍开展，但是校企合作 的依然停留在表层, 深度和广度有待将强。由于电子商务企业大型活动集中在双十一、618, 活动期间正好与高校的正常教学活动冲突, 这直接影响电子商务专业校企合作项目的开展。 目前, 电子商务专业校企合作大多停留在各自为营的阶段, 这不利于电子商务专业人才培养 校企合作的长期进行。

同时，由于实训经验不足，对相关细节把握不够，比如在高校与电商企业合作的过程中， 由于缺乏对学生必要的讲解和辅导, 导致学生因工资待遇、工作时间等问题工作热情不高, 抵触心理大, 实训效果偏低; 部分实习带队老师没有将电子商务行业发展的最新趋势和人才 需求反馈给学校, 导致电商专业就业率依然偏低; 还有一些电商企业仅仅为了使用廉价劳动 力与高校进行校企合作，这都导致校企合作无法达到相应的效果。 


\section{2 电子商务专业人才培养校企合作缺乏动力}

在校企合作的过程中，没有政府的优惠政策做后盾，电子商务企业和开设电商专业的高 校缺乏应有的动力。没有互惠互利就没有合作发展, 目前, 由于缺乏相应的税收、补助等优 惠政策, 电子商务类企业为了节省成本, 追求利润最大化, 普遍对于开展校企合作缺乏动力, 因此, 仅凭高校单方面热情, 在合作开展过程中必定困难重重。另外, 高校普遍教育资金紧 张、用地紧张，也需要政府提供相应的资金补贴和用地支持。

\section{3 缺乏健全的长效运行机制}

没有一个健全的长效运行机制, 开设电子商务专业的高校校企合作很难落到实处。在电 商人才培养校企合作中, 电商企业与学校办学之间不能统筹运作、整体优化, 进而无法构建 双方满意的预期目标。由于缺乏一定的激励机制, 高校电商专业的教师和电商企业的职业经 理人都对校企合作的积极性不高, 导致他们投入校企合作教学中的积极性不高, 直接影响校 企合作培养电商人才的成效。只有建立平等互利、资源共享、优势互补、利益均沾、风险共 担的长效运行机制，才能保证校企合作长期有效的开展。

\section{4 校企合作缺乏国家立法保证}

从国外校企合作模式发展来看, 大多数国家都制定了法律、法规和政策支持校企合作长 期发展。由于我国教育法制化程度不高, 进程缓慢, 难以满足社会经济发展和职业教育发展 的要求，这严重阻碍的了我国高校与企业校企合作长期、持续、深入的开展 ${ }^{[1]}$ 。

\section{4.电子商务专业人才培养校企合作优化策略}

保证电商专业人才培养校企合作长期有效进行, 不是一个单方面能解决的问题, 需要高 校、企业、政府和学生四方共同努力才可以, 就现实中电子商务专业校企合作出现的问题, 从以下四个方面提出优化策略。

\section{1 高校要为校企合作创设良好的基础和环境}

\subsection{1 以市场需求为导向进行专业设置和人才培养方案调整}

地方应用型本科院校的专业设置应该以市场需求为导向, 培养适合电子商务行业发展的 人才。开设电子商务专业的高校应该加强与电商企业的联系, 及时根据用人单位的用人需求, 做好新专业的申报和人才培养方案的调整，根据技术发展趋势开设人工智能、大数据、商务 智能等课程, 发展网络营销、跨境电商、农村电商等定向细分专业对电子商务专业进行优化, 进而提高电子商务专业学生的就业率。

\subsection{2 加强校企合作师资力量的互惠}

开设电子商务专业的高校要主动要求电商企业的职业经理人来校做兼职教师, 解决高校 教师实践能力薄弱的普遍问题, 作为互惠条件, 学校同时将优秀的专业教师派到电子商务类 企业进行理论指导和实践指导，帮助企业进一步发展，同时也有利于“双师型”教师队伍的建 设和发展。

\subsection{3 明确校企合作参与各方的权利和义务}

在电子商务专业人才培养的校企合作中，高校、企业、政府和学生四方相互作用、相互 影响, 要想让参与各方发挥良性作用, 并能持续深入的合作, 需要签署校企合作协议, 明确 各方的权利和义务, 用法律手段对各要素进行影响和约束, 进而维护各方的权利和义务。

4.1.4 设立校企合作管理委员会

开设电子商务专业的高校应聘请电子商务行业专业、企业高管、主管电子商发展的政府 领导共同组成校企合作管理委员会, 结合行业发展和地方经济发展定期对学校电子商务专业 设置、教学模式、社会实践进行考核。通常情况下，在电子商务校企合作管理委员会里要设 
置一个考核督导组, 对校企合作进行全方位的监督和管理, 及时查找问题、查漏补缺, 保证 校企合作的长效、深入开展 ${ }^{[2]}$ 。

\subsection{5 完善校企合作管理体系建设}

在校企合作中，开设电子商务专业的高校要坚持优化权利结构，下移管理中心，以电子 商务专业人才培养为目标, 完善校企合作管理体系建设, 实现校企合作依法管理、加强合作 监督，完善程序机制，为校企合作深入、长久开展奠定良好基础 ${ }^{[3]}$ 。

\section{2 提高企业参与校企合作的力度}

\subsection{1 协助高校建设全真实训基地}

电子商务企业要积极协助高校建设全真实训基地，提高电子商务专业人才的实践能力和 职业素养, 从而为电子商务类企业提供优秀人才。电子商务类企业要为高校学生和高校教师 提供职业技能训练和专业化培训的机会, 通过这种方式让高校师生能够了解电子商务岗位所 需的相关知识及技能, 便于学生查漏补缺, 及时上手相关工作。这就要求电子商务类企业要 完善自身的运营机制，将校企合作与企业人才储备、技术研发、社会服务紧密结合起来。

4.2.2 搭建校企合作资源共享平台

搭建校企合作资源共享平台，进行校企合作电子商务专业人才培养。例如，可以与高校 进行协调, 针对双十一、618等电子商务促销活动进行专项的企业实习实训活动, 根据实际情 况将实训场所设置在学校机房或校内实训室, 进而平衡学校正常教学秩序和企业电商旺季的 人才短缺压力。为了解决高校 “双师型” 教师短缺的问题, 电子商务企业的职业经理人, 尤其 是具有培训经历或教师资格的职业经理人进入高校担任电子商务专业的兼职教师 ${ }^{[4]}$ 。

\subsection{3 发展校企合作集团化模式}

电子商务专业的校企合作可以尝试集团化办学，这种模式由高校和电子商务大型企业成 立教育集团, 制定统一章程, 明确相关的权利和义务。电子商务教育集团对成员进行相关的 培训实施目标管理、强化程序监管、实施资金统管，实施人才互动，强化集团建设。电子商 务企业起主导作用, 可以优先接触到集团培养的优秀的电商专业人才, 对人才培养的方向、 课程安排进行方向性指引。为了实现校企合作集团化模式, 需要企业和高效找到双方利益的 契合点, 进一步提高办学效果。

\section{3 政府加大宏观调控力度}

\subsection{1 建立健全相关的法律法规}

为保证电子商务专业人才培养校企合作的进一步发展，政府应该尽快将高等将于校企合 作纳入法制化进程。首先, 可以对参与校企合作的企业进行税收减免、贷款优惠、人才培训 补助等优惠政策; 其次, 要完善考核办法, 根据企业参与校企合作的具体成效制定浮动的优 惠措施, 保证校企合作落到实处; 再者, 要构建财政支持法规政策体系, 建立校企合作保障 条例, 并纳入职业教育法, 以加快政策法规的法制化进程 ${ }^{[5]}$ 。

\subsection{2 提高职业证书在就业市场中的地位}

政府应该建立一套完善的电子商务职业就业准入制度，将职业证书和学历证书同时作为 用人单位相应岗位应具备的证书，按照不同的岗位职责进行持证上岗。电子商务企业在招聘 专业人才时要优先录用有职业资格证书的人才。随着电子商务行业竞争的日趋激烈, 电商企 业建立自己的人才培训中心已经成为大多数企业扩大规模，提高效益的有效途径。

\subsection{3 营造良好的校企合作氛围}

政府在维护学校、企业和学生三方利益的基础上, 要充分发挥政府的监督和调控作用, 通过制定和实施一系列校企合作的优惠政策，调动各方积极性，例如增加开展校企合作高校 的财政补贴, 减免学生学费, 减免合作企业税收等, 同时在舆论上要给与引导和鼓励, 保证 高校的校企合作生源和企业电商人才的引入规模 ${ }^{[6]}$ 。 


\section{4 学生要提高自我培养的主观意识}

通过校企合作，电子商务专业学生要及时了解电商岗位的技能要求，明确职业发展目标 和学习目标, 变“要我学”到“我要学”, 利用学校组织的社会实践, 不断提高自己解决问题的 能力和处理问题的技巧。

\section{致谢}

本文为河南省教育科学十三五规划课题《创新创业背景下应用型本科电子商务专业“三维 互动”教学模式研究与实践》（项目编号：2018-JKGHYB-0309）; 河南牧业经济学院校级教 育教学改革研究项目《基于协同创新理念的应用型本科电子商务专业立体化实践教学体系构 建及实践研究》（项目编号：2018-YBXM-001）、《“一带一路”战略背景下生鲜电商与冷链 物流课程构建研究》“(项目编号：2018-YBXM-036）；河南牧业经济学院科研创新基金项目

(项目编号：XKYCXJJ2017003）；河南牧业经济学院科研创新团队建设项目（项目编号： 2018KYTD02）、河南牧业经济学院校级教育教学改革研究示范项目《经管类应用型本科校 企合作人才培养模式的研究与实践》（项目编号：2018-SFXM-004）的阶段性研究成果之一。

\section{References}

[1] Jiao Minghai. Study on the disturbance of legal system on the vulnerability of higher vocational school enterprise cooperation and countermeasures [J]. Occupation, 2018 (21): 28-30.

[2] Xue Ning. Study on school enterprise cooperation mode of Tourism Higher Vocational Education [D]. Hebei Normal University, 2013.

[3] Zhao Shide, Shen Meng, Bi Jielin. Reflections on the cultivation of e-commerce professionals from the perspective of school enterprise cooperation -- Taking Huangshan University as an example [J]. Journal of Huainan Normal University, 2018,20 (03): 104-107.

[4] Zhao min. research on the construction of innovative and entrepreneurial e-commerce specialty [J]. E-commerce, 2018 (07): $67+75$.

[5] Xin Huan. Research on the current situation and Countermeasures of university enterprise cooperation in Higher Vocational Education [D]. Guangxi Normal University, 2016.

[6] Guo Haihua, Chen Peng. Problems in school enterprise cooperation and solutions [J]. Enterprise reform and management, 2018 (13): 207-208. 